\title{
Pedagogies in the Wild-Entanglements between Deleuzoguattarian Philosophy and the New Materialisms: Editorial
}

\author{
Evelien Geerts \\ University of Birmingham
}

\section{Delphi Carstens \\ University of the Western Cape}

\section{DOI: https://doi.org/10.1344/inmr.v1i3.33369}

Whether we are said to be living in the Anthropocene, the Capitalocene, or are witnessing the start of the Chthulucene,${ }^{1}$ as feminist science studies scholar Donna J. Haraway (2016) would describe the current post-anthropocentric era, there is a demonstratable need for affective, entangled, transversal forms of thinking-doing today. Writing this editorial almost a year after the COVID-19 pandemic erupted, and that as inhabitants of Belgium and South Africa-countries with complex ongoing capitalist-colonial legacies, socio-political presents, and heavily but also differently hit by said pandemic - we more than ever feel that these are times of entwined crisis, chaos, and hardship, overflowing with cravings for pedagogical-philosophical responses that are affirmative, productive, and future-oriented. Reactions that are moreover part theory, part praxis, counter the nihilistic, and are future-focused while still grounded in the present, as to not defer responsibilities to future times (see Geerts \& Carstens, 2019).

Critical race studies and queer of colour critique scholars such as José Esteban Muñoz (2009), Stefano Harney and Fred Moten (2013), and Saidiya Hartman (2020) have rethought the connections between the queer, the pedagogical, and the temporal. These thinkers have inspired queer theorist Jack Halberstam (2019) to posit that crisis times require a strategy that is peculiarly productive in its counterproductivity-times

\footnotetext{
${ }^{1}$ Introduced as a new geological era by Paul J. Crutzen (2006), the Anthropocene describes the colossal impact humans have had on the environment through industrial and other interventions. The Capitalocene, coined by Jason W. Moore (2013), presents a similar analysis, but additionally underlines the role of extractive capitalism. Haraway's (2016) Chthulucene, on the contrary, is a post-Anthropocene, post-Capitalocene era in which humans were to realise they are living together with other species and could and should do so in non-destructive ways.
} 
like these, in our regard, require thinking-doings that are abundantly wild. Wild in being, in becoming, in imagining, in thinking-doing. Wildness, as Halberstam (2019, $\mathrm{n}$. p.) puts it, calls us to pay attention to the "the emptied spaces of crumbling institutions and the destitution to come of environmental disaster," and find ways of counteracting "the madness of life under our present dictatorship of the callous and unimaginative." Wildness is not only "committed to mis/readings, refusals, dreaming, fugitivity, insurrection" (Halberstam, 2019, n. p.), but also to seeking out new intimacies, joys, pleasures, and affirmations that run against the grain of extraction-based capitalist realism (see Fisher, 2009). Wildness requires that we rethink modes of being and becoming by jumping the fences that separate divergent disciplines of knowledge and seeking out productive synergies with other non-canonical minoritarian/subjugated knowledges and more-than-human modes of understanding. Wildness, as Halberstam explains elsewhere, is "an epistemology, a terrain of alternative formulations that resist the orderly impulses of modernity ... a merging of anticolonial, anticapitalist, and radical queer interests" (2000, p. x).

\section{A Pedagogy of Wild Thinking-Doings}

In pursuing entangled "constellations of human-nonhuman agencies, forces and events" (Taylor \& Ivinson, 2013, p. 688), wildness in our regard finds productive expression in Deleuzoguattarian cartographic, schizoanalytic, rhizomatic, and nomadic praxes and their reformulations in feminist new materialist, queer theory, and queer of colour critique. These divergent praxes share wildness in common, asking that we recognise the surprising, important_if often unnoticed and mundane-work that objects, bodies, and phenomena do as material agents. As such, we, together with the authors in this special issue, would like to propose a wild pedagogy that requires us to rethink not only the nature, scope, and effects of materiality, but also forces us to recognise the immanence of materiality and ideality alike. Wildness obliges us to embed new forms of being-presence and being-in-becoming in our pedagogical and research practices, seeking out new individual, social, and environmental ecologies of production, action, and expression. 
Part of this wild pedagogical-philosophical outlook, and of feminist new materialist ${ }^{2}$ praxes in general (see e.g., Barad, 2007; Haraway, 2016; van der Tuin, 2015), is an attentive citational praxis that conceptualises referencing as something worldly embedded and thus with material-political effects. Largely working within the admittedly exclusivist domains of Continental philosophy and critical theory, cultivating reflexivity with regards to citational praxes certainly matters, as they themselves can carry over pre-existing absences and marginalisations, or as queer theorist Sara Ahmed (2013) has also aptly put it:

The reproduction of a discipline can be the reproduction of these techniques

of selection, ways of making certain bodies and thematics core to the discipline, and others not even part. (n. p.)

Non-reflexive disciplinary and other forms of knowledge get reiterated through the praxis of citing, as Ahmed also writes here, therefore fortifying "problematic hegemonies of knowledge production and authority" (Mott \& Cockayne, 2017, p. 959). Engaging with materialism-rooted but always speculative reflections-carrying feminist, critical race studies, and queer (of colour critique) approaches, as contemporary critical new materialist and posthumanist scholarship attempts to do, means engaging with entangled - but often still overlooked-matters of for instance sexuality, race and ethnicity, and bio-/necropolitics (also see Chen, 2012; Jackson, 2020; Mbembe, 2017; Shotwell, 2016).

\section{Deleuzoguattarian and Feminist New Materialist Thinking-Doings}

Taken the foregoing into account, we therefore use philosophers Gilles Deleuze and Félix Guattari's rhizomatic, ecosophic, and transversal geophilosophy (see, for example, 1983, 1987, and 1994) as our departure point-since they still represent a Continental minoritarian tradition-but not the end point of this wild philosophising adventure. Broadly speaking, Deleuze and Guattari's combined output is concerned with the problematic of late liberal capitalism, a crisis which has infiltrated and

\footnotetext{
2 Both Barad (2007) and van der Tuin (2015, p. xiv) propose a type of feminist new materialist philosophy that builds on the feminist theories that have come before by, respectively, highlighting a diffractive reading and citational methodology and an affirmative transgenerational, transversal type of feminism. Haraway (2016) does so, too, and combines the above approaches with a pedagogicaltransgenerational one, often generously citing graduate students, younger colleagues, and artists.
} 
extended over all aspects of social, economic, cultural, and personal life, and since the 1980s has melted together with a distinct globalised neoliberal ethos. Along with more contemporary queer and new materialist scholars, Deleuze and Guattari in their combined and separate oeuvres argue for wild ecosophic perspectives that foster dissensus and dissidence in our reconstruction of entangled individual, social, and environmental practices and ecologies that defy the real of machinic capitalist, extraction-based realism and its atomistic ontologies of discrete identity.

This is a challenge that Guattari specifically takes up in The Three Ecologies (2000, p. 24), where he explains that "ecosophic problematic is that of the production of human existence itself in [the] new historical contexts" of late capitalism, "whose sweeping progress cannot be guaranteed to continue as it has." Similar eco-focused and/or capitalism-critical analyses have been made by various feminist new materialists, such as the already-mentioned Haraway (2016), but also Stacy Alaimo (2016), Rosi Braidotti (2013), Mel Y. Chen (2012), Melinda Cooper (2008), Elizabeth Grosz (2017), María Puig de la Bellacasa (2017), and Alexis Shotwell (2016). Braidotti and Grosz, in particular, can be regarded as Deleuzoguattarian new materialists, pushing Deleuze and Guattari's thought into feminist directions (see e.g., Braidotti 2002, 2006, and 2011). Along with Cooper, these thinkers present a new materialist philosophy that underlines the dangers of a neoliberal capitalist hypermarketed society. Arguing that every single being is currently at risk of being completely commodified, and, eventually, disposed of-starting with those whose bodies have already been constructed to not matter that much, of course, as late liberal capitalism is rooted in colonial modernity and its racial logics (see e.g., Chakravartty \& Ferreira Da Silva, 2012) —these new materialists understand only too well the bio/necropolitical game of extractive capitalism that Guattari (2000) seeks to resist.

The COVID-19 pandemic is, in this sense, but another manifestation of a crisis created and supported by a capitalist system that has converted the earth's systems and beings into marketable resources. Looking at Shotwell's (2020), Braidotti's (2020), and queer theorist Judith Butler's (2020) recent analyses of said pandemic, all three thinkers agree that the COVID-19 crisis is a more-than-human one. We therefore are in need of a proper posthumanist critical vocabulary and lens to examine the continuous reproduction of the virus in its various parasitic encounters with its human and non-human hosts, such as cardboard boxes, doorknobs, small, unventilated 
classroom spaces, cats, and many other phenomena that become entangled with the agential SARS-CoV-2 virus. Butler and Braidotti connect the crisis back to its extractive, environment-damaging capitalist roots: Butler (2020, n. p.) in fact warns of the damaging effect of the Trumpian "cost-benefit" analysis currently in use, which serves to intensify the already pre-existing inequalities created by capitalism. Braidotti (2020, p. 1), in turn, claims that the current neoliberal capitalist regime has re-created "a recurrent sense of hopelessness or impossibility" that has deep roots in the history of capitalism and colonialism. These analyses do not constitute a nihilistic wallowing or naive glorification of a virus-free future. Rather, as Braidotti (2020, p. 2) points out, while the current crisis calls for a "mourn[ing of] the dead, humans and non-humans," it also calls us toward "a more transversal, relational ethics that encompasses nonhumans" and the previously dehumanised. Such a project encourages us to seek resonances between new materialist and Deleuzoguattarian strategies of wildness that move away from discrete individuality toward a recognition that the substance of the human individual is ultimately entangled with that of the collective and the planetary environment.

Ecosophy, as wild pedagogical modus of resistance to capitalism's economic logicsand, indeed, to the recurrent sense of hopelessness that it generates, particularly in the current time of disruption, crisis, and imbalance-means thinking and doing transversally across mental, social, and environmental ecologies. These three interlinked registers have suggested a way of structuring the responses of the authorcontributors to this special issue, as we have outlined it below. These registers, like the contributions to this volume, do not occupy distinctive territories but inhabit entangled ethico-political and ethico-aesthetic landscapes and ways of thinking-doing that are interchangeable. Each of these registers-mental, social, and environmental-are governed, as is each of the contributions to this volume, by an eco-logic, that concerns itself with movements, intensities, and overlapping processes but also a search for cohesion. As with everything in Deleuzoguattarian thought, there are no discrete individualised essences, systems, or registers as such; instead, there are only processes that continually strive to articulate aspects of existence engaged in continual processes of mutation and repose. What interests these thinkers-what makes them (be)wild(ering) - is their attraction to dissident vectors and modes of expression that run counter to the normal vectors of subjectification and 
singularisation. Each process or ecology in their wild ontology-whether mental, social, or environmental-is, as Guattari (2000, p. 36) puts it, "not given in-itself, closed in on itself, but instead as a for-itself that is precarious, finite, finitised, singular, singularised, capability of bifurcating into stratified and deathly repetitions or of opening up processually from a praxis that enables it to be made 'habitable' by a human project."

\section{Enacting a Wild Cartography across Three Registers}

Reworking the modus of the clinical psychoanalytical session, Guattari (2000) introduces affective (pre-personal), non-objective, and fragmentary registers as ways of invigorating nascent subjectivities that enable the coming-into-being of individual psyches in relation to and with collective formations and environmental assemblages. As with the entirety of the Deleuzoguattarian oeuvre, Guattari is interested in how subjectivity can be reworked via points of rupture as it intersects and becomes with society and the environment. In this way he, along with Deleuze, promotes innovatory minoritarian practices that enable the expansion of alternative experiences centred around a respect for singularity, relationality, and the continuous production of an autonomising subjectivity that can articulate itself appropriately in relation to the rest of society as well as to a more-than-human ecology. Guattari (p. 38) reminds us that in undertaking such a creative task we need to remain vigilant and "face up to the logic of desiring ambivalence wherever it emerges -in culture, everyday life, work, sport," educational settings, etc.- "in order to re-evaluate the purpose of work and of human activities according to a different criteria" than that of "profit and yield."

Francisco B. Trento, writing in this volume, queers notions of hospitality and diplomacy by drawing our attention to neurotypicality's equivocal logic of sameness. Trento argues that social ecologies_particularly educational ones_need to be made wild to accommodate a diversity of non-normative mental ecologies. By merging Baradian, Derridean, and Deleuzoguattarian perspectives around relational ontologies, Trento undertakes a queering of educational/collective modes of hospitality and diplomacy by exposing them to the contingent plasticity of diverse subjectivities. Elina Oinas attempts a similar merging between mental and collective ecologies, suggesting that a wild-pedagogical praxis begins in the middle, between 
individual and group subjectivities where the isolated intersects with the relational. Oinas observes that the wild is both connected and solitary; the impetus to be courageous and free in one's academic research can be lonely and isolating, while the opposite risk-adverse impulse brings stability but also suffocation.

Working from the premise of a socius that is not frozen but constantly mutating, Deleuze and Guattari (1987) suggest ways of extending the reorganisation of primary subjectivity as it develops in human social groups, as well as in encounters with morethan-human agential objects, forces, and affects. For Guattari (2000, p. 47), the "major crisis of our era"-the constantly expanding existential territory of neoliberal capitalism—dulls these encounters, while agitating and neuroticising the socius. This necessitates wild practices that seek out ways in which the social can deterritorialise from mass media formulations and reterritorialise around new connections, significations and assemblages that re-define the socius in more fluid ways. Wildness remains a necessary aesthetic, ethical, ontological, and epistemological paradigm that allows for the "reconquest of creative autonomy" in the social field and the "catalyst for a gradual reforging and renewal of humanity's confidence in itself."

Writing in this volume, Andy Broadey formulates a genealogy of educational/artistic/protest events that queer the facialisation/racialisation machines that continue to persist in the socius of integrated global capitalism. Drawing on the notion of the undercommons, Broadey foregrounds a series of minoritarian experiments/becomings and encounters that resist, quare, make-strange, question, and jostle the collective normopathic imperatives that facialise and racialise. In such a manner, Broadey develops a future-orientated Deleuzoguattarian schizopedagogy that sets its compass around the minoritarian, staging a reconstruction of the social ecology as it intersects with mental and environmental ecologies, while reconceptualising the fabrics of the pedagogical, to echo Broadey's claims. Coming at this problematic from a different perspective-that of academic subjectivity as it intersects with algorithmic counting practices-Susan O. Cannon and Maureen Flint argue for a citational politics that resists the hyper-individualising, competitive, and normopathic forces of neoliberal capitalism. Moving away from the domesticating and controlling tendencies induced by the research metrics of online research platforms, these authors seek out the unpredictable, contagious, and creative aspects of algorithmic counting practices to explore the wild possibilities they offer for reinventing 
academic citizenship and collective academic ecologies along more creative, mutational and relational/response-able lines.

Articulating much more than the simple defence of nature, Deleuze and Guattari (1987) are interested in ways in which nature resists classification and attempts at hierarchical mapping processes. The transversal approach that these thinkers invoke involve taking on board the environmental/more-than-human ecologies that exist prior to social groups and individual. They articulate an environment that is not static but engaged in a continuous process of being reinvented and reformulated. As such, they are interested in the creation of new modes of thought and praxis. New modes of thinking and doing_or thinking-doings_imply new meaning-making practices that redefine and replace the narrative of biblical genesis and the hierarchy of tree diagrams that privilege humans (specifically, certain types of human) and foreground modes of economisation and extraction.

The loss of biodiversity and the destruction of ecosystems brought about by neoliberal economisation and anthropocentrism destroys more-than-human entanglements. In countering this Jacqueline Viola Moulton, writing in this special issue, takes us into more-than-human shared worlds where relational assemblages are being undone. As ocean/land resources and ecologies are being eroded around us in the Anthropocene, Moulton draws our attention to a more-than-human ethics of care that inheres in shared affective languages beyond words and which exists prior to and beyond human individual/collective identities. We are asked, in this way, to construct environmental ecologies of mourning and care that resist the relentless anthropocentricism and privileging of words. There is a great deal of restoration and learning to be enacteda rejuvenation that requires an acknowledgement of entanglement, an awareness of more-than-human affect and attentiveness to more-than-human care. Moulton reminds us, along with Haraway and Guattari, that words are the bricks and mortar with which individual lives are built in this destructive and collective world-making we call the Anthropocene.

Raewyn Martyn writes that re-worlding and rewilding our narratives and aesthetics is necessary if we wish to break from the narratives that sustain what Guattari (2000) terms integrated world capitalism. This necessary work requires an attentiveness to the ways in which individual and collective ecologies materially entangle with the environmental ecology. It also necessitates, as both Martyn and Grosz suggest, an 
onto-ethical lens; "a way of thinking about not just how the world is but how it could be, how it is open to change, and, above all, the becomings it might undergo" (Grosz, 2017 , p. 1). Working with the responsive morphology of biopolymers in her artpedagogical practices that span the fluid boundaries of individual, collective and environmental ecologies, Martyn suggests plasticity as an open-ended onto-aesthetic paradigm appropriate to more open-ended ecologies that are able to resist and refuse the intractability of the capitalist status quo.

A reflective essay by jan jagodzinski both investigates and problematises the gestation of a wild onto-ethical/onto-aesthetic paradigm. In attempting to bewilder itself, pedagogy encounters a flowing together of affects, concepts, and technologies; a confluence that finds itself overshadowed by neoliberal regimes of control as well as by the onset of the Anthropocene. Increasingly porous boundaries between the organic and inorganic, the material and immaterial, call for speculative fabulations appropriate to the equivocal nature of this new geological age. Taking inspiration from Deleuzian vitalism and exploring as well as problematising some of its various new materialist manifestations, jagodzinski's speculative essay explores the idea of in|difference as a toolbox for constructing wild pedagogical assemblages capable of tackling the Anthropocene crisis.

An entry from the digital New Materialism Almanac-by Evelien Geerts and Iris van der Tuin-plus a new almanac-styled piece by Sam Skinner, trace the respective cartographies of diffraction and liquid agency. This epigrammatic narrative interlude is followed by a re-view of Braidotti's Posthuman Knowledges (2019) and Bessie Dernikos', Nancy Lesko's, Stephanie McCall's, and Alyssa Niccolini's Mapping the Affective Turn in Education (2020) by Kathryn Strom and Tammy Mills. This creative thinking together with and through two texts explores and enacts affective scratchings that explore - in a carefree manner-what it might mean to enact an affirmative ethics and map entangled more-than-human assemblages. Together, the almanac entries and re-view serve as brief interludes between the more extensive article contributions and the irruptions-filled intra-view that concludes this special issue. Here, the special issue editors, along with Chantelle Gray and Aragorn Eloff, conclude on a more pressing note by underlining productive tensions, diffractions, and resonances between Deleuzoguattarian and new materialist stratagems and concepts; particularly as these pertain to the urgency of gestating bewildering more-than-human affect-laden 
wild pedagogies. The creation of such a pedagogy-one that can fluidly traverse Guattari's (2000) three ecological registers in a manner appropriate to our current watershed moment-is, as this roundtable makes clear, more than urgent. After all, as the current pandemic has hopefully made apparent, the dam wall that is holding back all the dire consequences of capitalist realism/business-as-usual is merely an illusory screen. In reality, the cracks have been showing for a long time already_by now they are gaping fissures.

While, as Haraway (2016) hopes, the ensuing cauldron of Anthropocene climatechanges, pandemics, cascading species-losses, widening economic precarity, sociopolitical violence, and fascist revanches might lead to a more hopeful Chthulucene, it is up to us to configure this more buoyant figuration. We are all called upon to channel the floodwaters that are now upon us in a manner appropriate to such times of uncanny more-than-human entanglements. The wild beckons us away from protective anthropocentric screens of comfort and denialism that keep us from enacting the wilding that is now so desperately needed. We are called toward the challenging work of building a better world/worlding for a community-to-come-a wilding work that will affirm materiality itself in all its entangled more-than-human complexity. There is, consequently, much work to be done as we attempt to reclaim pedagogy from the deadening and world-annihilating clutches of capitalist logics.

For Deleuze and Guattari, difference and creative autonomy are integral to the processual ecosophical engagements of a wild pedagogy, which aims for a continual reforging and renewal of ideas and pedagogical principles. Along with the authors in this volume, and as we affirm in our concluding intra-view, the central premise of Deleuzoguattarian wildness is this: that relational-albeit tangled-pathways across various disciplines of knowledge and, indeed, across mental, social, and environmental ecologies, are not only possible and desirable but unavoidable and necessary. To face this crisis that has come to be known as the Anthropocene, we will need to enact a wild pedagogy that is able to onto-ethically and ethico-politically take stock of the differential scales and speeds at which this event is occurring. To solve this dilemma, we require a pedagogy that is able to reach for the immanence between ideality and materiality; an immanence that implies much epistemological and political pedagogical work as we do the necessary work of traversing mental, social and environmental registers. For Deleuzoguattarian/new materialist thinkers, pedagogues, 
artists, and activists, as for the authors whose work graces this special edition, it is transversality-the potential for thinking outside of capitalism's reification of binary logics - that creates a vital critical counter-response and that calls us toward wild pedagogical-philosophical practices.

\section{Acknowledgements}

This work is based on the research supported in part by the National Research Foundation of South Africa (Grant Number: 120845) and inspired by the methodological conversations that have already taken place in the context of the Urban Terrorism in Europe (2004-19): Remembering, Imagining, and Anticipating Violence project. The special issue editors would like to thank the contributing authors for their wonderful, timely pieces, Chantelle Gray for her intellectual generosity, all of Matter's staff members we communicated and worked with during the past rather overwhelming year, and our furry companion critters that supported us through it all.

\section{Bibliography}

Ahmed, Sara (2013, September 11). Making feminist points. Feministkilljoys. https://feministkilljoys.com/2013/09/11/making-feminist-points/.

Alaimo, Stacy (2016). Exposed: Environmental politics and pleasures in posthuman times. University of Minnesota Press.

Barad, Karen (2007). Meeting the universe halfway: Quantum physics and the entanglement of matter and meaning. Duke University Press.

Braidotti, Rosi (2002). Metamorphoses: Towards a materialist theory of becoming. Polity Press.

Braidotti, Rosi (2006). Transpositions: On nomadic ethics. Polity Press.

Braidotti, Rosi (2011). Nomadic subjects: Embodiment and sexual difference in contemporary feminist theory. 2nd edition. Columbia University Press. Originally published in 1994.

Braidotti, Rosi (2013). The posthuman. Polity Press.

Braidotti, Rosi (2020). 'We' are in this together, but we are not one and the same. Journal of Bioethical Inquiry, 1-5. https://doi.org/10.1007/s11673-020-10017-8. 
Butler, Judith (2020, March 30). Capitalism has its limits. Verso. https://www.versobooks.com/blogs/4603-capitalism-has-its-limits.

Chakravartty, Paula \& Ferreira Da Silva, Denise (2012). Accumulation, dispossession, and debt: The racial logic of global capitalism-An introduction. American Quarterly, 64(3), 361-385. https://doi.org/10.1353/aq.2012.0033.

Chen, Mel Y. (2012). Animacies: Biopolitics, racial mattering, and queer affect. Duke University Press.

Cooper, Melinda (2008). Life as surplus: Biotechnology and capitalism in the neoliberal era. University of Washington Press.

Crutzen, Paul J. (2006). The 'Anthropocene'. In: E. Ehlers and T. Krafft (Eds.), Earth System Science in the Anthropocene (pp. 13-18). Springer.

Deleuze, Gilles \& Guattari, Félix (1983). Anti-Oedipus: capitalism and schizophrenia. (R. Hurley, M. Seem \& Lane. H, Trans). University of Minnesota Press. Originally published in French 1972.

Deleuze, Gilles \& Guattari, Félix (1987). A thousand plateaus: capitalism and schizophrenia. (B. Massumi, Trans.). University of Minnesota Press. Originally published in French 1980.

Deleuze, Gilles \& Guattari, Félix (1994). What is philosophy? (H. Thomlinson \& G. Burchell, Trans.). Columbia University Press. Originally published in French 1991.

Fisher, Mark (2009). Capitalist realism: Is there no alternative? Zero books.

Geerts, Evelien \& Carstens, Delphi (2019). Ethico-onto-epistemology. Philosophy Today, 63(4), 915-925. https://doi.org/10.5840/philtoday202019301.

Grosz, Elizabeth (2017). Incorporeal: Ontology, ethics, and the limits of materialism. Columbia University Press.

Guattari, Félix (2000). The three ecologies. (I. Pindar and P. Sutton, Trans.). Continuum. Originally published in French in 1989.

Halberstam, Jack (2019, February 25). Strategy of wildness. Critique \& Praxis, 13(13). http://blogs.law.columbia.edu/praxis1313/jack-halberstam-strategy-of-wildness/.

Halberstam, Jack (2020). Wild things: The disorder of desire. Duke University Press.

Haraway, Donna J. (2016). Staying with the trouble: Making kin in the Chthulucene. Duke University Press.

Harney, Stefano \& Moten, Fred (2013). The undercommons: Fugitive planning \& black study. Minor Compositions. 
Hartman, Saidiya (2020). Wayward lives, beautiful experiments: Intimate histories of riotous black girls, troublesome women, and queer radicals. W. W. Norton \& Company.

Jackson, Zakiyyah I. (2020). Becoming human: Matter and meaning in an antiblack world. New York University Press.

Mbembe, Achille (2017). Critique of black reason. (L. Dubois, Trans.). Duke University Press.

Moore, Jason W. (2013, May 13). Anthropocene, Capitalocene, and the myth of industrialization: Part I. World-ecological imaginations. https://jasonwmoore.wordpress.com/2013/05/13/anthropocene-or-capitalocene/.

Mott, Carrie \& Cockayne, Daniel (2017). Citation matters: Mobilizing the politics of citation toward a practice of 'conscientious engagement.' Gender, Place \& Culture, 24(7), 954-973. https://doi.org/10.1080/0966369X.2017.1339022.

Muñoz, José Esteban (2009). Cruising utopia: The then and there of queer futurity. New York University Press.

Puig de la Bellacasa, María (2017). Matters of care: Speculative ethics in more than human worlds. The University of Minnesota Press.

Shotwell, Alexis (2016). Against purity: Living ethically in compromised times. The University of Minnesota Press.

Shotwell, Alexis (2020, May 5). The virus is a relation. Upping the Anti: A Journal of Theory and Action. https://uppingtheanti.org/blog/entry/the-virus-is-a-relation.

Taylor, Carol A. \& Ivinson, Gabrielle (2013). Material feminisms: New directions for education. Gender and Education, 25(6), 665-670. https://doi.org/10.1080/09540253.2013.834617.

Van der Tuin, Iris (2015). Generational feminism: New materialist introduction to a generative approach. Lexington Books.

\section{Author Information}

\section{Evelien Geerts (e.m.l.geerts@bham.ac.uk)}

Evelien Geerts is a multidisciplinary philosopher and Research Fellow at the University of Birmingham, where she is working on the ERC-funded Urban Terrorism in Europe (2004-19): Remembering, Imagining, and Anticipating Violence project. She holds a Ph.D. in Feminist Studies and History of Consciousness (DE) from the University of California, Santa Cruz. Her research interests include new materialisms \& 
Deleuzoguattarian philosophy, critical epistemologies, political philosophical questions of identity, difference, and violence, and critical and diffractive pedagogies. She previously has published in Philosophy Today, Women's Studies International Forum, and Rhizomes: Cultural Studies in Emerging Knowledge-publications that can be found at www.eveliengeerts.com-and is a Posthumanities Hub affiliated researcher plus a PhEMaterialisms member.

\section{Delphi Carstens (carstensdelphi@gmail.com)}

Delphi Carstens is a lecturer at the University of the Western Cape. He holds a Ph.D. (in apocalyptic science fictional literature and philosophy) from Stellenbosch University. His research interests and publications include the Anthropocene/Capitalocene, Deleuzoguattarian pedagogical interventions, uncanny science fictions, and sorcerous new materialisms. His publications include, amongst others, chapters in edited volumes by Palgrave, Sternberg, Bloomsbury, and Taylor and Francis. as well as journal articles in The South African Journal of Higher Education (SAJHE), Education as Change, Alternation, CriSTal, Parallax, and Somatechnics. 